\title{
Ketersediaan Aksesibilitas Wisata bagi Penyandang Disabilitas di Kota Bandung dan Sekitarnya
}

\author{
Afiati* $^{*}$ \\ Prodi Perencanaan Wilayah dan Kota, Fakultas Teknik, Universitas Islam \\ Bandung, Indonesia. \\ *afiati.ajjah@gmail.com
}

Abstract. Tourism is a journey carried out by a person from one area to another. At this time the City of Bandung, Bandung Regency and West Bandung Regency which are part of the Bandung Basin Urban Area which is a Provincial Strategic Area, there are various types of tourism but the current conditions are still not friendly for people with disabilities seen the number of disabilities Bandung City is $0.089 \%$ from the total population. Based on this, the problems in this study are formulated as follows: (1) What is the condition of tourist objects that have met the availability of physical accessibility for people with disabilities? (2) What are the Non-Physical Accessibility Conditions for Persons with Disabilities?. The researcher uses a human instrument approach with qualitative descriptive research methods from reducing data, presenting data and conclusions. The informants in this study were 3 people with visual impairments, 4 people with disabilities who were deaf, 4 people with physical disabilities, 1 tour manager, 1 person from the tourism office, and 1 disability companion. With the sampling technique, namely snowball and purposive sampling with the validity test carried out is triangulation techniques, data sources and theories. The results of this study are: (1) There are 3 tourist sites that have met accessibility for disabilities (2) Non-physical accessibility conditions at tourist sites still do not meet the needs of disabilities.

Keywords: Tourism, Disabilities, Physical Accessibility and Non-Physical Accessibility

Abstrak. Pariwisata merupakan sebuah perjalanan yang dilakukan seseorang menuju suatu wilayah selain dari wilayah asalnya. Pada saat ini Kabupaten Bandung, Kabupaten Bandung Barat dan Kota Bandung yang merupakan Kawasan Perkotaan Cekungan Bandung dalam Kawasan Strategis Provinsi terdapat berbagai jenis wisata akan tetapi kondisinya saat ini masih kurang ramah bagi penyandang disabilitas dilihat dari jumlah disabilitas Kota Bandung adalah 0,089\% dari keseluruhan jumlah penduduk. Dalam hal ini maka permasalahan pada penelitian dirumuskan seperti berikut: (1)Bagimana Kondisi Objek Wisata yang Sudah Memenuhi Ketersediaan Aksesibilitas Fisik Bagi Penyandang Disabilitas? (2) Bagaimana Kondisi Aksesibilitas Non Fisik Bagi Penyandang Disabilitas ?. Peneliti menggunakan pendekatan human instrument dengan metode penelitian deskriptif kualitatif dari muai mereduksi data, penyajian data sampai penarikan kesimpulan. Informan pada penelitian ini adalah 3 orang disabilitas tuna netra, 4 orang disabilitas tuna rungu, 4 orang disabilitas tuna daksa, 1 orang pengelola wisata, 1 orang dinas pariwisata, dan 1 orang pendamping disabilitas. Pengambilan Sample menggunakan teknik snowball dan purposive sampling dengan uji validitas yang dilakukan adalah triangulasi teknik, sumber data dan teori. Berdasarkan penelitian yang sudah dilakukan terdapat hasil sebagai berikut : (1) Terdapat 3 lokasi wisata yang sudah memenuhi aksesibilitas bagi disabilitas (2) Kondisi aksesibilitas non fisik di lokasi wisata masih belum memenuhi kebutuhan disabilitas.

Kata Kunci: Pariwisata, Penyandang Disabilitas, Aksesibilitas Fisik dan Aksesibilitas Non Fisik 


\section{A. Pendahuluan}

Pariwisata adalah aktivitas perjalanan seseorang yang datang dan tinggal di suatu wilayah tertentu selain dari wilayah yang biasa ia tinggali dengan tujuan untuk bersantai dengan kurun waktu yang kurang dari satu tahun. (Hasanuddin, 2019). Pariwisata ramah disabilitas merupakan pariwisata yang menyediakan kebutuhan bagi difabel dalam bentuk atraksi, aksesibilitas, informasi dan transportasi (Asmaradana et al., 2019) selain itu juga dapat didukung dengan adanya cara pandang atau sikap seseorang dalam bersosialisasi (Mokhtar, 2019) denga para difabel.

Hambatan bagi penyandang disabilitas dalam pariwisata itu ada beberapa aspek diantaranya yaitu Informasi (Agovino et al., 2017), Sarana dan prasarana (Kurniawan \& Susilowati, 2016), dan aksesibilitas (Ozturk et al., 2008). Dalam Quran Surat A; - Fath Ayat 17 dikatakan bahwa tidak ada perbedaan antar manusia dimata Allah SWT. Selain itu dalam 17 tujuan Sustainable Development Goals (SDGs) dalam point ke-11 dengan tujuan Kota dan Permukiman yang berkelanjutan yang pada targetnya adalah " Tersedianya ruang public dan ruang terbuka hijau yang mudah di jangkau, inklusif dan aman salah satunya bagi penyandang disabilitas pada tahun 2030."

Pada tahun 2019 jumlah penyandang disabilitas di Kota Bandung adalah 0,089\% dari jumlah keseluruhan penduduk Kota Bandung yaitu 2.444.160 jiwa dan ada peluang mereka melakukan wisata satu kali dalam satu tahun, dilihat dari kondisi pariwisata saat ini masih belum ramah bagi disabilitas maka dengan adanya penelitian ini juga dapat mendukung terrealisasikannya SDG's point 11 tersebut. Pada penelitian ini aksesibilitas yang dimaksud adalah kemudahan bagi seseorang untuk menjangkau atraksi yang ada di lokasi wisata baik dari segi aksesibilitas non fisik dan aksesibilitas fisik bagi penyandang disabilitas.

Maka dari itu maka dari itu pariwisata ramah merupakan pariwisata yang dapat memenuhi kebutuhan aksesibilitas fisik dan aksesibilitas non fisik yang sesuai bagi keterbatasan dari setiap disabilitas diantaranya tuna rungu, tuna netra dan tuna daksa dalam menjangkau atraksi wisata yang disediakan. Adapun penelitian terdahulu yang membahas disabilitas terkait pelayanan publik, taman kota, studi fasilitas, taman ramah disabilitas dan destinasi ramah difabel (Kurniawan \& Susilowati, 2016), (Aprilesti \& Syaodih, 2019), (Zakiyah et al., 2017), (Nihayati \& Rekta, 2017) . Sedangkan penelitian terkait wisata ramah berdasarkan aksesibilitas bagi disabilitas di Kota Bandung dan sekitarnya ini belum ada.

Dilihat dari latar belakang diatas, berikut ini adalah tujuan penelitian yaitu untuk mengidentifikasi pariwisata ramah berdasarkan aksesibilitas bagi penyandang disabilitas. Dengan begitu pariwisata dapat mudah dinikmati oleh setiap orang bahkan penyandang disabilitas sekalipun. Berdasarkan dari tujuan diatas adapun sasaran dilakukannya penelitian ini adalah :

1. Identifikasi Kondisi dan Ketersediaan Aksesibilitas Fisik Bagi Penyandang Disabilitas

2. Identifikasi Kondisi Aksesibilitas Non Fisik Bagi Penyandang Disabilitas

\section{B. Metodologi Penelitian}

Dalam UUD 1945 Penyandang Disabilitas merupakan warga negara Indonesia yang perlu dilindungi hak - haknya. Dalam penelitian ini terdapat 3 jenis penyandang disabilitas yaitu:

1. Tuna Netra, merupakan seseorang yang memiliki hambatan dalam penglihatan yang terdapat 2 golongan dari tuna netra yaitu tidak melihat total (buta / totally blind) dan kemampuan melihat yang rendah (low vision)

2. Tuna Rungu, merupakan keadaan seseorang yang tidak dapat menangkap berbagai ransangan khususnya pada pendengarannya, terdapat dua kategori dari tuna rungu yaitu sama sekali tidak mendengar (tuli/ deaf) dan kurang pendengaran (low of hearing)

3. merupakan keadaan seseorang yang mengalami kerusakan akibat adanya hambatan atau gangguan pada sendi, tulang, otot yang dapat diakibatkan oleh pesejak lahir, penyakit, ataupun kecelakaan.

Adapun kriteria fasilitas inklusif menurut Tim Penyusun PSLB UB dikutip dari (Hasanuddin, 2019) adalah : 
1. Pintu

2. Tangga

3. Ramp

4. Toilet

5. Area Parkir
6. Permukaan Kemiringan

7. Layar Vidio

8. Jalur Pedestrian

9. Jalur Pemandu

10. Rambu dan Marka untuk mencari data yang dibutuhkan, maka dari itu pendekatan penelitiannya adalah human instrument dimana peneliti akan bertindak sebagai instrument juga pengumpul data. Metode analisis yang akan dilakukan adalah analisis deskriptif kualitatif dengan cara menganalisis, menggambarkan, dan meringkas berbagai situasi dari apa yang telah dilakukan selama pengamatan langsung di lapangan. Kegiatan dalam menurut Miles and Huberman analisis data terbagi menjadi 3 yaitu : reduksi data, penyajian data dan penarikan kesimpulan.

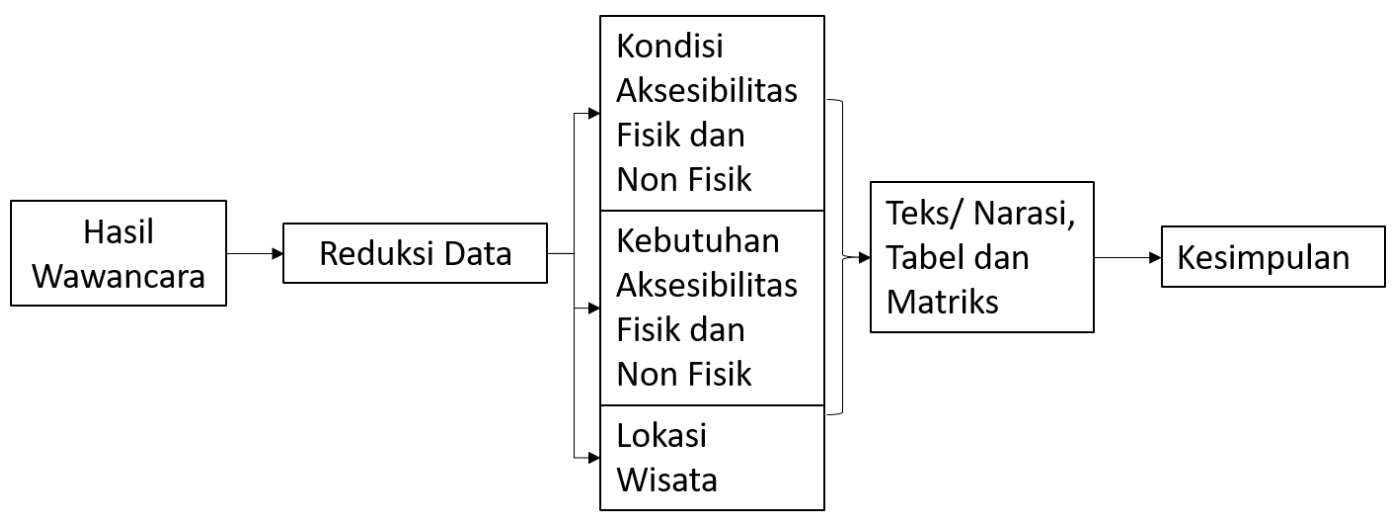

Gambar 1. Proses Analisis Penelitian

Pada penelitian ini pengumpulan data dilakukan dengan teknik wawancara, dokumentasi dan observasi dengan uji validitas data yang dilakukan adalah teknik triangulasi pengumpulan data, triangulasi sumber data baik dari disabilitas, pendamping dan pemerintah/ pengelola, dan triangulasi teori baik dari teori terdahulu/ kebijakan, sasaran dan hasil penelitian. Kemudian terdapat dua teknik pengambilan sample yaitu purposive degan memilih informan yang sesuai dengan penelitian dan snowball dengan mecari informan dan berhenti ketika jawaban informan sudah mulai jenuh atau berulang maka dari itu didapatlah 14 informan yang terdiri dari 3 orang tuna netra, 4 orang tuna rungu, 4 orang tuna daksa, 1 orang pengelola wisata, 1 orang dinas pariwisata, dan 1 orang pendamping disabilitas.

\section{Hasil dan Pembahasan}

Kota Bandung dan Sekitarnya merupakan salah satu kawasan dimana terdapat banyak sekali objek wisata terutama wisata alam dan buatan yang terdapat di 3 wilayah kabupaten dan kota yang ada di Jawa Barat yaitu Kabupaten Bandung, Kabuaten Bandung Barat dan Kota Bandung. Adapun alasan dipilihnya 10 (sepuluh) lokasi wisata tersebut dikarenakan memiliki jumlah pengunjung yang cukup banyak dibandingan dengan lokasi wisata lainnya dengan jumlah pengunjung pertahun adalah The Great Asia Afrika 500.757 jiwa, Farm House 271.554 jiwa, floating market 304.888 jiwa, kebun begonia 72.639, The Lodge 91.442 jiwa, fairy garden 179.137 jiwa selain jumlah wisatawan fairy garden ini juga merupakan salah satu destinasi wisata ramah difabel di Indonesia berdasarkan artikel yang diterbitkan oleh kemenparekraf RI tanggal 27 Mei 2021 , lembang zoo 276.903, kebun binatang 107.800 jiwa, the kings 480.000 jiwa juga salah satu wisata buatan yang memiliki letak strategis karena lokasinya yang berdekatan dengan alun-alun Kota Bandung dan situ patenggang 96.323 jiwa. Lebih jelasnya ada pada Tabel 1.1 Ruang Lingkup Wilayah Studi Berikut: 
Tabel 1. Lokasi Wisata Penelitian

\begin{tabular}{|c|l|c|l|}
\hline No & \multicolumn{1}{|c|}{ Nama Wisata } & Jenis Wisata & \multicolumn{1}{c|}{ Lokasi Wisata } \\
\hline 1 & Kebun Binatang & Wisata Buatan & Kec. Coblong - Kota Bandung \\
\hline 2 & Kings Shopping Center & Wisata Buatan & Kec. Regol - Kota Bandung \\
\hline 3 & Situ Patenggan & Wisata alam & Kec. Rancabali - Kab Bandung \\
\hline 4 & Fairy Garden & Wisata Buatan & Kec Lembang - Kab Bandung Barat \\
\hline 5 & The Great Asia Afrika & Wisata Buatan & Kec Lembang - Kab Bandung Barat \\
\hline 6 & Farm House & Wisata Buatan & Kec Lembang - Kab Bandung Barat \\
\hline 7 & Kebun Begonia & Wisata Buatan & Kec Lembang - Kab Bandung Barat \\
\hline 8 & Lembang Zoo & Wisata Buatan & Kec Lembang - Kab Bandung Barat \\
\hline 9 & The Lodge Maribaya & Wisata alam & Kec Lembang - Kab Bandung Barat \\
\hline 10 & Floating Market & Wisata Buatan & Kec Lembang - Kab Bandung Barat \\
\hline
\end{tabular}

Sumber: Identifikasi Pribadi, 2021

\section{Identifikasi Kondisi dan Ketersediaan Aksesibilitas Fisik Bagi Penyandang Disabilitas}

Kondisi dari setiap aksesibilitas fisik untuk kemudahan disabilitas daam mengakses atraksi yang ada di lokasi wisata sendiri adalah sebagai berikut:

1. Area Parkir (AP); dari 10 lokasi wisata sudah menyediakan tempat parkir yang luas akan tetapi masih belum ada parkir yang bertanda khusus penyandang disabilitas sehingga akan cukup sulit menjangkau pintu masuk pada saat banyak pengunjung wisata.

2. Pintu Masuk (PM); kondisi pintu masuk di setiap lokasi wisata sudah memenuhi kriteria aksesibel bagi enyandang disabilitas karena rata - rata sudah lebih dari $80-90 \mathrm{~cm}$, dan beberaa lokasi sudah menyediakan ramp dan jalur khusus bagi kursi roda.

3. Tangga $(\mathrm{T})$; indicator penting tangga adalah adanya handrail dari 10 lokasi wisata masih belum semua menyediakan handrail di sisi tangga dan kemiringan masih ada yang melebihi $60^{\circ}$ sehingga masih ada yang belum memenuhi kriteria aksesibel disabilitas.

4. Lift / Gondola (L/G); tidak semua lokasi wisata membutuhkan lift atau gondola, untuk saat ini di lokasi yang sudah menyediakan lift dan gondola sudah cukup luas dan ada petunjuk tetapi masih belum ada alarm peringatan untuk setiap disabilitas.

5. Ramp (R); dari 10 lokasi wisata hanya 3 lokasi wisata yang tidak menyediakan ramp, secara keseluruhan ramp di setiap lokasi wisata sudah memenuhi kriteria dan dapat mempermudah disabilitas mengakses atraksi yang disediakan.

6. Rambu / Marka (R/M); dari setiap lokasi wisata sudah menyediakan rambu atau marka secara umum akan tetapi untuk detail seperti petunjuk arah di ubin, penjelasan setiap atraksi masih belum semua lokasi menyediakan.

7. Toilet (TO); toilet yang disediakan dilihat dari kemudahan dibuka dan ditutup, petunjuk pemakaian, dan khusus kursi roda. Akan tetapi saat ini yang menyediakan hal tersebut masih 3 -5 lokasi wisata dari 10 lokasi wisata penelitian.

8. Jalur Pedestrian (JPD); dari 10 lokasi wisata sudah semua menyediakan jalur pedestrian yang luas dan sesuai kriteria baik dari segi ubin maupun minimal lebar jalur pedestrian tersebut, sehingga sudah aksesibel bagi setiap disabilitas.

9. Jalur Pemandu (JPM); dari 10 lokasi wisata semuanya masih belum menyediakan jalur pemandu baik itu untuk mengakses dari parkir ke pintu masuk maupun untuk mengakses atraksi wisata yang disediakan.

10. Visual (V); dari semua lokasi wisata hanya ada 1 yang menyediakan visual yaitu farmhouse dan itu pun masih belum menjelaskan lokasi wisata secara keseluruhan jua belum ada teks maupun peraga dalam pemberian informasi visual tersebut.

11. Klarifikasi Raba Dengar (KRD); klarifikasi raba dengar merupakan replica atraksi yang dipadukan dengan audio, untuk saat ini di setiap lokasi wisata belum menyediakan dan sangat dibutuhkan untuk memberi informasi melalui perabaan bagi disabilitas tuna netra khususnya.

Berdasarkan kriteria aksesibilitas fisik bagi penyandang disabilitas berbeda - beda 
berdasarkan kekurangan dari setiap penyandang disabilitas, berikut ini merupakan ketersediaan aksesibilitas fisik berdasarkan kondisi di lokasi wisata adalah sebagai berikut:

Tabel 2. Ketersediaan Aksesibilitas Fisik Tuna Netra

\begin{tabular}{|c|c|c|c|c|c|c|c|c|c|c|c|}
\hline \multirow{2}{*}{ No } & \multirow{2}{*}{ Lokasi Wisata } & \multicolumn{9}{|c|}{ Aksesibilitas Fisik Berdasarkan Kriteria Tuna Netra } & \multirow{2}{*}{ Ket } \\
\hline & & $\mathbf{A P}$ & PM & $\mathbf{T}$ & $\mathbf{L} / \mathbf{G}$ & $\mathbf{R} / \mathbf{M}$ & TO & JPD & JPM & KRD & \\
\hline 1 & The Great Asia Afrika & $\sqrt{ }$ & $\sqrt{ }$ & $\mathrm{x}$ & $\sqrt{ }$ & $\mathrm{x}$ & $\mathrm{x}$ & $\sqrt{ }$ & $\mathrm{x}$ & $\mathrm{x}$ & 4 \\
\hline 2 & Farm House & $\sqrt{ }$ & $\sqrt{ }$ & $\sqrt{ }$ & $\mathrm{x}$ & $\mathrm{X}$ & $\sqrt{ }$ & $\sqrt{ }$ & $\mathrm{x}$ & $\mathrm{x}$ & 5 \\
\hline 3 & Floating Market & $\sqrt{ }$ & $\sqrt{ }$ & $\mathrm{x}$ & $\mathrm{x}$ & $\mathrm{X}$ & $\mathrm{x}$ & $\sqrt{ }$ & $\mathrm{x}$ & $\mathrm{x}$ & 3 \\
\hline 4 & Kebun Begonia & $\sqrt{ }$ & $\sqrt{ }$ & $\sqrt{ }$ & $\mathrm{x}$ & $\mathrm{x}$ & $\sqrt{ }$ & $\sqrt{ }$ & $\mathrm{x}$ & $\mathrm{x}$ & 5 \\
\hline 5 & The Lodge & $\sqrt{ }$ & $\sqrt{ }$ & $\sqrt{ }$ & $\mathrm{x}$ & $\mathrm{x}$ & $\sqrt{ }$ & $\sqrt{ }$ & $\mathrm{x}$ & $\mathrm{x}$ & 5 \\
\hline 6 & Fairy Garden & $\sqrt{ }$ & $\sqrt{ }$ & $\sqrt{ }$ & $\mathrm{x}$ & $\mathrm{x}$ & $\sqrt{ }$ & $\sqrt{ }$ & $\mathrm{X}$ & $\mathrm{x}$ & 5 \\
\hline 7 & Lembang Zoo & $\sqrt{ }$ & $\sqrt{ }$ & $\sqrt{ }$ & $\mathrm{x}$ & $\mathrm{x}$ & $\mathrm{x}$ & $\sqrt{ }$ & $\mathrm{x}$ & $\mathrm{x}$ & 4 \\
\hline 8 & The Kings & $\sqrt{ }$ & $\sqrt{ }$ & $\sqrt{ }$ & $\sqrt{ }$ & $\sqrt{ }$ & $\mathrm{x}$ & $\sqrt{ }$ & $\mathrm{x}$ & $\mathrm{x}$ & 6 \\
\hline 9 & Kebun Binatang & $\sqrt{ }$ & $\sqrt{ }$ & $\sqrt{ }$ & $\mathrm{x}$ & $\mathrm{x}$ & $\sqrt{ }$ & $\sqrt{ }$ & $\mathrm{x}$ & $\mathrm{x}$ & 5 \\
\hline 10 & Situ Patenggang & $\sqrt{ }$ & $\sqrt{ }$ & $\mathrm{x}$ & $\mathrm{x}$ & $\mathrm{x}$ & $\mathrm{x}$ & $\sqrt{ }$ & $\mathrm{x}$ & $\mathrm{x}$ & 3 \\
\hline
\end{tabular}

Sumber: Identifikasi Pribadi, 2021

Tabel 3. Ketersediaan Aksesibilitas Fisik Tuna Netra

\begin{tabular}{|c|c|c|c|c|c|c|c|c|c|c|}
\hline \multirow[t]{2}{*}{ No } & \multirow[t]{2}{*}{ Lokasi Wisata } & \multicolumn{8}{|c|}{$\begin{array}{c}\text { Aksesibilitas Fisik Berdasarkan Kriteria Tuna } \\
\text { Rungu }\end{array}$} & \multirow[t]{2}{*}{ Ket } \\
\hline & & $\mathbf{A P}$ & $\overline{\mathbf{P M}}$ & $\mathbf{T}$ & $\mathbf{L} / \mathbf{G}$ & $\mathrm{R} / \mathrm{M}$ & TO & JPD & $\mathbf{V}$ & \\
\hline 1 & The Great Asia Afrika & $\sqrt{ }$ & $\sqrt{ }$ & $\sqrt{ }$ & $\sqrt{ }$ & $\sqrt{ }$ & $\sqrt{ }$ & $\sqrt{ }$ & $\mathrm{x}$ & 7 \\
\hline 2 & Farm House & $\sqrt{ }$ & $\sqrt{ }$ & $\sqrt{ }$ & $\mathrm{x}$ & $\sqrt{ }$ & $\mathrm{x}$ & $\sqrt{ }$ & $\sqrt{ }$ & 6 \\
\hline 3 & Floating Market & $\sqrt{ }$ & $\sqrt{ }$ & $\sqrt{ }$ & $\mathrm{x}$ & $\sqrt{ }$ & $\mathrm{x}$ & $\sqrt{ }$ & $\mathrm{x}$ & 5 \\
\hline 4 & Kebun Begonia & $\sqrt{ }$ & $\sqrt{ }$ & $\sqrt{ }$ & $\mathrm{x}$ & $\sqrt{ }$ & $\mathrm{x}$ & $\sqrt{ }$ & $\mathrm{x}$ & 5 \\
\hline 5 & The Lodge & $\sqrt{ }$ & $\sqrt{ }$ & $\sqrt{ }$ & $\mathrm{x}$ & $\sqrt{ }$ & $\sqrt{ }$ & $\sqrt{ }$ & $\mathrm{x}$ & 6 \\
\hline 6 & Fairy Garden & $\sqrt{ }$ & $\sqrt{ }$ & $\sqrt{ }$ & $\mathrm{x}$ & $\sqrt{ }$ & $\sqrt{ }$ & $\sqrt{ }$ & $\mathrm{x}$ & 6 \\
\hline 7 & Lembang Zoo & $\sqrt{ }$ & $\sqrt{ }$ & $\sqrt{ }$ & $\mathrm{x}$ & $\sqrt{ }$ & $\mathrm{x}$ & $\sqrt{ }$ & $\mathrm{x}$ & 5 \\
\hline 8 & The Kings & $\sqrt{ }$ & $\sqrt{ }$ & $\sqrt{ }$ & $\sqrt{ }$ & $\sqrt{ }$ & $\sqrt{ }$ & $\sqrt{ }$ & $\mathrm{x}$ & 7 \\
\hline 9 & Kebun Binatang & $\sqrt{ }$ & $\sqrt{ }$ & $\sqrt{ }$ & $\mathrm{x}$ & $\sqrt{ }$ & $\mathrm{x}$ & $\sqrt{ }$ & $\mathrm{x}$ & 5 \\
\hline 10 & Situ Patenggang & $\sqrt{ }$ & $\sqrt{ }$ & $\sqrt{ }$ & $\mathrm{x}$ & $\sqrt{ }$ & $\mathrm{x}$ & $\sqrt{ }$ & $\mathrm{x}$ & 5 \\
\hline
\end{tabular}

Sumber: Identifikasi Pribadi, 2021 
Tabel 4. Ketersediaan Aksesibilitas Fisik Tuna Netra

\begin{tabular}{|c|l|c|c|c|c|c|c|c|c|c|}
\hline \multirow{2}{*}{ No } & \multirow{2}{*}{ Lokasi Wisata } & \multicolumn{10}{|c|}{ Aksesibilitas Fisik Berdasarkan Kriteria Tuna Daksa } & \multirow{2}{*}{ Ket } \\
\cline { 3 - 11 } & & AP & PM & T & L/G & R & R/M & TO & JPD & \\
\hline 1 & The Great Asia Afrika & $\mathrm{x}$ & $\sqrt{ }$ & $\mathrm{x}$ & $\sqrt{ }$ & $\sqrt{ }$ & $\sqrt{ }$ & $\mathrm{x}$ & $\sqrt{ }$ & 5 \\
\hline 2 & Farm House & $\mathrm{x}$ & $\sqrt{ }$ & $\sqrt{ }$ & $\mathrm{x}$ & $\sqrt{ }$ & $\sqrt{ }$ & $\sqrt{ }$ & $\sqrt{ }$ & 6 \\
\hline 3 & Floating Market & $\mathrm{x}$ & $\sqrt{ }$ & $\mathrm{x}$ & $\mathrm{x}$ & $\mathrm{x}$ & $\mathrm{x}$ & $\mathrm{x}$ & $\sqrt{ }$ & 2 \\
\hline 4 & Kebun Begonia & $\mathrm{x}$ & $\sqrt{ }$ & $\sqrt{ }$ & $\mathrm{x}$ & $\sqrt{ }$ & $\mathrm{x}$ & $\mathrm{x}$ & $\sqrt{ }$ & 4 \\
\hline 5 & The Lodge & $\mathrm{x}$ & $\sqrt{ }$ & $\mathrm{x}$ & $\mathrm{x}$ & $\mathrm{x}$ & $\mathrm{x}$ & $\mathrm{x}$ & $\sqrt{ }$ & 2 \\
\hline 6 & Fairy Garden & $\mathrm{x}$ & $\sqrt{ }$ & $\sqrt{ }$ & $\mathrm{x}$ & $\sqrt{ }$ & $\sqrt{ }$ & $\sqrt{ }$ & $\sqrt{ }$ & 6 \\
\hline 7 & Lembang Zoo & $\mathrm{x}$ & $\sqrt{ }$ & $\mathrm{x}$ & $\mathrm{x}$ & $\sqrt{ }$ & $\sqrt{ }$ & $\sqrt{ }$ & $\sqrt{ }$ & 5 \\
\hline 8 & The Kings & $\mathrm{x}$ & $\sqrt{ }$ & $\sqrt{ }$ & $\sqrt{ }$ & $\sqrt{ }$ & $\sqrt{ }$ & $\mathrm{x}$ & $\sqrt{ }$ & 6 \\
\hline 9 & Kebun Binatang & $\mathrm{x}$ & $\sqrt{ }$ & $\sqrt{ }$ & $\mathrm{x}$ & $\sqrt{ }$ & $\sqrt{ }$ & $\sqrt{ }$ & $\sqrt{ }$ & 6 \\
\hline 10 & Situ Patenggang & $\mathrm{x}$ & $\sqrt{ }$ & $\mathrm{x}$ & $\mathrm{x}$ & $\mathrm{x}$ & $\mathrm{x}$ & $\mathrm{x}$ & $\sqrt{ }$ & 2 \\
\hline
\end{tabular}

Sumber: Identifikasi Pribadi, 2021

Tabel 5. Ketersediaan Aksesibilitas Fisik Berdasarkan Lokasi Wisata

\begin{tabular}{|c|l|l|l|}
\hline \multirow{2}{*}{ No } & \multicolumn{2}{|c|}{ Lokasi Wisata Berdasarkan Ketersediaan Kriteria Disabilitas } \\
\cline { 2 - 4 } & \multicolumn{1}{|c|}{ Tuna Netra } & \multicolumn{1}{c|}{ Tuna Rungu } & \multicolumn{1}{c|}{ Tuna Daksa } \\
\hline 1 & Farm House & The Great Asia Afrika & The Great Asia Afrika \\
\hline 2 & Kebun Begonia & Farm House & Farm House \\
\hline 3 & The Lodge & Lodge & Fairy Garden \\
\hline 4 & Fairy Garden & Fairy Garden & Lembang Zoo \\
\hline 5 & Kebun Binatang & The Kings & The Kings \\
\hline 6 & The Kings & & Kebun Binatang \\
\hline
\end{tabular}

Sumber: Identifikasi Pribadi, 2021

Tabel 6. Lokasi Wisata yang Memnuhi Kriteria Aksesibilitas Fisik

\begin{tabular}{|r|l|}
\hline No & \multicolumn{1}{|c|}{ Lokasi Wisata } \\
\hline 1 & FarmHouse \\
\hline 2 & Fairy Garden \\
\hline 3 & The Kings \\
\hline
\end{tabular}

Sumber: Identifikasi Pribadi, 2021

Berdasarkan tabel diatas terdapar 3 lokasi wisata yang sudah cukup memenuhi kriteria dengan melihat kondisi lokasi wisata untuk penyandang disabilitas adalah FarmHouse, Fairy Garden dan The Kings.

\section{Identifikasi Kondisi Aksesibilitas Non Fisik Bagi Penyandang Disabilitas}

Kondisi aksesibilitas non fisik dilihat dari hasil wawancara kepada setiap informan seperti dikatakan juga oleh pak basri selaku penyandang disabilitas tuna netra:

“...yang pernah kita datangi ya kalau kita yang tuna netra ya sedapat gambaran yang diceritakan oleh keluarga kita saja. Apa yang dia dapat ceritakan apa yang dia dapat gambarkan yang paling sering kan nanti dirabakan." (Wawancara di SLB YRBB,2021)

Kemudian dikatakan juga oleh Indri selaku peyandang disabilitas tuna netra seperti:

"Biasa aja sih gak terlalu perhatian paling kaya cuma silakan gitu, Suka nemu aja ada waktu itu oh ada mau apa Teh ini menu makanannya kan kita gak tau ya terus aduh mas tolong 
ke kita mah harus dijelasin oh iya maaf katanya" (Wawancara di Floating Market, 2021)

Kondisi aksesibilitas non fisik lainnya yaitu dari tuna rungu seperti dikatakan oleh auryn: "kak aku pernah ke farm house, disana waktu beli tiket jd kaya ditanya dulu keluhannya gimana jadi kita bisa ngejelasin kalau kita tuli terus beli tiketnya jadi di peragain pakai tangan mau beli 1 atau 2 tiket, kalau di farm house udah cukup ada tanda - tanda yang bis akita kenalin dan palayannya sudah cukup baik soalnya bisa mengerti kekurangan kita kalau waktu di tebing keraton untuk beli tiket aja susah untuk komunikasinya"

Dikatakan juga oleh nadya selaku tuna rungu kondisi aksesibilitas non fisik adalah:

"beberapa lokasi memang ada yang pelayananya sudah ramah ada juga yang belum, untuk informasi yang didapat ditunjukin sama keluarga karena pelayan karyawan belum bisa bahasa isyarat supaya komunikasi nya lancar" (Via Zoom Meeting, 2021)

Selain itu ada juga aksesibilitas non fisik menurut tuna daksa seperti yang dikatakan wanda dan winny:

"gak jarang juga kalau misalnya si karyawannya itu gak tau caranya kan dari tim kita suka ngajarin "jadi gini caranya mas" gitukan suka diajarin juga. Kitakan manggungnya itu suka takut kadang-kadang mahasiswanya juga harus diajarin sama tim kita caranya gimana gitu. Iya jadi biar kitanya gak jatoh biar aman gitu” (rumah Wanda dan Winny, 2021) seperti:

Selain itu ada juga menurut saeful kahfi selaku penyandang disabilitas tuna daksa

"untuk saat ini karyawan masih kurang gerak cepat dalam membantu kami dan belum ada helper seperti di finlandia dalam melakukan wisata di lokasinya menyediakan helper untuk membantu disabilitas kalua untuk di Indonesia sejauh ini belum ada yang sadar langsung membantu" (Via Zoom Meeting, 2021)

Berdasarkan dari pernyataan - pernyataan dari disabilitas maupun beberapa pihak terkait memang kondisi saat ini di beberapa lokasi wisata belum memenuhi kebutuhan khusus bagi penyandang disabilitas selain dari pemerintah yang belum memiliki regulasi khusus dan hanya berupa surat edaran atau himbauan kepada pengelola sehingga pada pihak pengelola pun belum ada pelatihan terkait bagaimana cara khusus untuk melayani penyandang disabilitas, dilihat dari keterbatasan setiap disabilitas itu berbeda - beda maka ada juga cara khusus untuk menanganinya dan saat ini di lokasi wisata masih melayani wisatawan pada umumnya saja dan membantu secara umum sesuai informasi yang diminta dari disabilitas tersebut.

\section{Kesimpulan}

Berdasarkan penelitian dan pembahasan yang sudah dilakukan sebelumnya, berikut ini merupakan kesimpulan dari hasil yang didapat:

1. Berdasarkan kondisi dan ketersediaan aksesibilitas fisik dari 10 lokasi wisata yang dijadikan objek penelitian terdapat 3 lokasi wisata yang sudah memenuhi kriteria aksesibilitas bagi disabilitas yaitu Farm House, Fairy Garden dan The Kings.

2. Kondisi saat ini di beberapa lokasi wisata belum memenuhi kebutuhan khusus bagi penyandang disabilitas selain dari pemerintah yang belum memiliki regulasi khusus dan hanya berupa surat edaran atau himbauan kepada pengelola sehingga pada pihak pengelola pun belum ada pelatihan terkait bagaimana cara khusus untuk melayani penyandang disabilitas, dilihat dari keterbatasan setiap disabilitas itu berbeda - beda maka ada juga cara khusus untuk menanganinya dan saat ini di lokasi wisata masih melayani wisatawan pada umumnya saja dan membantu secara umum sesuai informasi yang diminta dari disabilitas tersebut.

3. Berdasarkan analisis yang sudah dilakukan pariwisata ramah merupakan pariwisata yang dapat menyediakan kebutuhan konsumen dalam mengakses atraksi wisata, konsumen pada penelitian ini merupakan penyandang disabilitas sehingga terdapat beberapa kebutuhan penyandang disabilitas untuk menjangkau atraksi wisata dalam konteks aksesibilitas fisik dan aksesibilitas non fisik yang dibutuhkan. 


\section{Acknowledge}

Terima Kasiih kepada Kedua Orang Tua, Ibu Gina Puspitasari Rochman ST.,MT selaku pembimbing penelitian, keluarga dan kerabat dekat, informan dan rekan - rekan planologi 17 yang sudah memberikan semangat dan motivasi untuk dapat terselesaikannya penelitian ini.

\section{Daftar Pustaka}

[1] Agovino, M., Casaccia, M., Garofalo, A., \& Marchesano, K. (2017). Tourism And Disability In Italy. Limits And Opportunities. Tourism Management Perspectives. Elsevier Science Ltd. Vol 23. Napoli. Page 58-67.

[2] Aprilesti, L. P., \& Syaodih, E. (2019). Persepsi Penyandang Disabilitas Terhadap Taman ( Studi Kasus Taman Inklusi Dan Taman Lalu Lintas. Prosiding Perencanaan Wilayah dan Kota. Unisba. Kota Bandung. Vol 5 No 2. Hal 1-6.

[3] Asmaradana, A., Sakinah, N., \& Sari, P. 2019. Revitalisasi Wisata Halal Dan Pemberdayaan Difabelpreneur Berbasis Iot Menuju Indonesia Berdikari. Studi Kasus Wisata Ciwidey, Jawa Barat. Universitas Gunadarma. Depok.

[4] Hasanuddin, M. (2019). Analisis Fasilitas Pariwisata Di Museum Angkut Kota Batu Bagi Pengunjung Penyandang Disabilitas. Jurnal Administrasi Bisnis. Universitas Brawijaya. Malang. Vol 72 No 2. Hal 138-147.

[5] Kurniawan, E., \& Susilowati, F. (2016). Perlindungan Hukun Bagi Penyandang Disabilitas Terhadap Kemudahan Dalam Beraktivitas di Ruang Publik di Kota Surabaya. Jurnal Hukum. Universitas Negri Surabaya. Surabaya. Vol 3 No 4. Oktober 2016.

[6] A. Samad Abd A. Rahim Abdul (2019). The Anticipation Of Malaysian Urban Cities To Be Inclusive And Accessible By 2030. Intellectual Discourse. International Islamic University Malaysia. Kuala Lumpur. Vol 27 No SI 2. Desember 2019. Page 889-897.

[7] Nihayati, L., \& Rekta, D. (2017). Aksesibilitas Merapi Park World Landmark Sebagai Destinasi Yang Ramah Difabel. Jurnal Arsitektur Kota dan Permukiman. Universitas Muslim Indonesia. Vol 4 No 2. Agustus 2019. Hal 61-66.

[8] Ozturk, Y., Yayli, A., \& Yesiltas, M. (2008). Is The Turkish Tourism Industry Ready For A Disabled Customer's Market?. The Views Of Hotel And Travel Agency Managers. Tourism Management. Elsevier. Ankara. Vol 29 No (2), March 2007. Page 382-389.

[9] Sugiyono. (2018). Metode Penelitian Kuantitatif, Kualitatif, dan Kombinasi (Mixed Metods). Bandung : Alfabeta.

[10] Zakiyah, U., \& Husein, R. (2016). Pariwisata Ramah Penyandang Disabilitas. Journal Of Governance And Publik Policy. Universitas Muhammadiyah Yogyakarta Vol 3 No 3. Oktober 2016. Hal 482-505. 